\title{
Rabbis Jeremy Collick, David Goldberg, Harry Jacobi, Ernst Stein and Charles Wallach
}

\author{
Jonathan Magonet
}

Tounded in 1956, Leo Baeck College is a relatively young institution - in the world of rabbinic seminaries, yet it has been in existence long enough to witness the passing of a number of distinguished rabbis who have graduated from its programme. Sadly this 'in memoriam' commemorates the death of five such rabbis within the period of a year, each of whom has served the Jewish community and beyond, each of whom leaves a significant legacy and whose absence is a serious loss to family and friends, the communities they have served and the wider world. They came from very different backgrounds: two of them born in pre-war Germany, refugees who came late in life to rabbinic studies; two of them born and educated in the UK; one born in South Africa. They served in a variety of congregational settings: in the UK and continental European Liberal congregations; one worked within the Einheitsgemeinde system in Berlin, and one in the emerging Masorti movement in the UK; one served South Africa and Australia as well. They each offered a unique set of personal qualities and experience to the task.

\section{Rabbi Dr Jeremy Collick, 31 August 1957-21 February 2019}

Rabbi Jeremy Collick was born in London, grew up within the UK Reform movement and wanted to be a rabbi from his childhood. He obtained a BEd at Trent Park College and studied history and Jewish history at University College London. While undertaking rabbinic studies at Leo Baeck College, he also spent time at the Jewish Theological Seminary in New York and Los Angeles. He was ordained in 1983 and served as rabbi in Brighton and Hove Reform Synagogue from 1984 to 1999. He earned a PhD from Pacific Western University with a thesis on 'Some 
Titles and Roles of the Sages'. He became the rabbi of Edgware Masorti Synagogue, celebrated for his teaching skills, the warmth and generosity of his outreach to the members of the community. Sadly, he had to take early retirement because of chronic ill-health. He was four days away from a long-held desire to make Aliyah to Israel with his wife and two sons, when he was admitted to hospital and diagnosed with liver cancer.

Rabbi Collick is survived by his wife Cindy and sons Jacob and Joel.

Rabbi Collick reflected on the rabbi's pastoral role as a hospital visitor based on his personal perspective of someone himself confined to hospital for long periods of time: ${ }^{1}$

After more than eleven weeks in various hospitals I am, hopefully, on the way to recovery. It has been very strange being 'on the other side of the bed', so to speak, after thirty-five years as a congregational rabbi. Visiting people who were unwell, disabled and unable to get out, or approaching the frontier of this world, filled up more than half my working life until ill-health forced me to retire two years ago.

I was never sure that my visits made a real difference to those I was trying to comfort but, after all, it is what rabbis do. And, of course, our tradition encourages us to visit the sick; it is something that God Himself did when Abraham was recovering from his brit milah in the Torah. For the rabbis, visiting and comforting the sick was a great mitzvah and even helped to take away some of the pain.

And it is true, it is lonely being a patient. Even though so much is happening, it can be a very lonely time. Visitors do help - family, friends, rabbis and even the occasional Roman Catholic chaplain made the time go a little quicker. As did my wife's constant infusions of hot chicken soup.

But it's not just visits that have helped me to cope. At the Royal Free and at other hospitals in London, a group of people have got together to perform a wonderful mitzvah. The charity is called Ezra Umarpeh and provides a Jewish room with wonderful hot Shabbat meals under Kedassia supervision, for patients and their families, together with challah, grape juice and even battery-powered Shabbat candles transporting us, if only for a short time, back to reality and normality.

It's not just that sense of physical isolation of loneliness, of somehow being cut off from day-to-day life that we may hate. When we suffer an enforced break due to illness, death of a loved one or simply retirement from a busy professional or business life, there is a sense of despair and the feeling that we mean less to those around us and maybe even to God.

In hospital it is so easy to become institutionalised, to suffer the many indignities we undergo and to become, in the attitude and speech of well-meaning medical professionals, 'the patient', a number and an illness category rather than a human being. And maybe, sometimes, we 
even become disconnected from God. Those who are regular shul-goers, or even irregular ones, can miss the feeling of reaching the Holy One surrounded with the ritual beauty of Torah, the ner tamid and the hustle and bustle that are part of our services.

Of course, we can and do pray by ourselves. We can find God and some peace even in the midst of great pain and anxiety. I find great comfort in davening alone at home or in hospital, though I have long since lost faith in the idea which we sing about in Ki Hineh Kachomer during the High Holy Days, that just like the potter who strikes his pots to strengthen them, so God tests only those who can withstand and grow from the pain, and not those who'll crack.

So for me, after the joy of human company and a plate of chicken soup, the final mitzvah to counter that sense of isolation is, perhaps, the most contentious.

When I was rabbi of Edgware Masorti Synagogue, I was asked many times whether we could or should livestream our services. While we gave it quite a lot of thought, in the end, we decided not to go ahead with the idea.

There are halachic challenges to broadcasting services live, as well as social and communal issues about the importance of minyan and praying (with the occasional conversation), not to mention schmoozing at kiddush, all of which are part of the Shabbat experience. And, of course, the question as to whether people would be tempted to tune in at home as an alternative to going to shul.

However, having been in hospital for so long, the worst day of each week, without doubt, was Shabbat; few visitors, no TV and no services. After much heartache, I used my laptop to be part of the Shabbat morning service of a Conservative synagogue in Chicago and spent an incredible morning transported back to my world, to Shabbat and the wonderful feeling of being a part of what we Jews do. I then switched to West London Synagogue's service with its sense of calm and peace - not my style but beautiful nonetheless.

The halachic issues for the shul are easily overcome - a fixed camera focuses on the shaliach tzibbur or the ark on a time-switch. The benefits to housebound congregants or those in hospital are incalculable. Adding a sense of community and Shabbat joy - and I could comment on the rabbi's sermon to my heart's content!

The halachic issues facing the user are more complicated and I will need to look up the teshuvot available.

In the meantime, however, my answer to the question as to whether we can or should stream our services online is a resounding 'Yes' (Posted on 11 July 2016). 


\section{Rabbi Dr David Goldberg, OBE, 25 February 1939-30 April 2019}

The son of Rabbi P. Selvin Goldberg and his wife Frimette, David Goldberg was born in London and raised in Manchester, where his father was the celebrated rabbi of Manchester Reform Synagogue. He studied at Oxford University and Trinity College Dublin and received rabbinic ordination from Leo Baeck College in 1971. He served as minister of Wembley and District Liberal Synagogue (c. 1971-1975) before joining the Liberal Jewish Synagogue, St. John's Wood (LJS), initially as associate rabbi, becoming senior rabbi in 1989 until 2004 when he was named rabbi emeritus. His decision to join LJS was because of the respect he felt for the intellectual and academic qualities and integrity of Rabbi John Rayner and Rabbi Dr David Goldstein who were ministers there.

Known as an outstanding preacher, he was always forthright in his opinions. He was often criticised for his views on the Israel-Palestinian conflict, being the first Anglo-Jewish rabbi to call for the recognition of legitimate Palestinian rights in an article in the Times in 1978. While a staunch advocate of the right of Israel to exist, he was deeply concerned about ethical responsibilities and the Jewish commitment to the centrality of justice in human affairs. His views on the subject were expressed in three of his five books: To the Promised Land: A History of Zionist Thought (1996); The Divided Self: Israel and the Jewish Psyche Today (2005) and This Is Not the Way: Jews, Judaism and the State of Israel (2012).

He pioneered interfaith dialogue, initiating local meetings of Jews, Christians and Muslims between the Liberal Jewish Synagogue, the Regent's Park Mosque and St John's Wood Church. In 1999 he was the first Jew to recite the Kaddish, the memorial prayer, in Westminster Abbey, at the memorial gathering for Lord (Yehudi) Menuhin and in the same year received the gold medal of the International Council of Christians and Jews. For his interfaith work he was awarded an OBE in 2004.

Rabbi Goldberg is survived by his wife Carole, their son Rupert and daughter Emily, and grandson Oscar.

Rabbi Goldberg's personal wrestling with issues of religious belief and contemporary humanistic values is illustrated in this extract from a sermon delivered at LJS on the eve of Yom Kippur 2005:

But as philosophers and other thinkers have come to recognise, the supposed death of God has led to the dissolution of any ultimate or absolute structures of value. Belief in God may be dismissed by anthropologists and social scientists as just one more example of a general human 
tendency to posit something wholly external to the human condition as the foundation of its meaning or worth. If there is a God, the thought goes, then His will would confer absolute authority on a particular system of values, and hence a particular way of living. But if there is no God and all value systems are simply human interpretations, then why should one have more claim on us than any other? All are equally subjective, arbitrary and lacking in ultimate authority. No wonder that this has resulted in the spread of moral and political relativism and social anarchy. As Dostoyevsky acutely argued in The Brothers Karamazov, once God is declared dead, everything is permitted. When our world view is egocentric not theocentric, when Man, not God, is placed at the centre of the universe, then inevitably there will be competing ideologies and weird sects clamouring for our allegiance, ignorant armies clashing by night.

Am I advocating, then, a return to traditional belief in God, even though Reason and modern knowledge tell us that many of the attributes formerly ascribed to God are no longer sustainable? Of course not. As one example, it seems to me that the theory of evolution, despite its flaws, is more likely to be correct than the theological argument for intelligent design. Or again, Judaism's insistence that there is a divine purpose to history, culminating in the establishment of God's kingdom on earth, is more a pious hope than a realistic expectation. History, to my way of thinking, is simply one darn thing after another, a perennial struggle between good and evil. God does not intervene in history. We pray and work for the messianic age all the more keenly for knowing that it will never happen in our lifetime.

No, what I am arguing for is a world view that sees our lives and freewill actions not merely in the here and now, but by the remorseless light of an ultimate judge and arbiter. That ultimate judgement is delivered by the One whom we call God, not the hard-to-believe-in God of miracles and fanciful claims, but the God who impels us to right conduct, the power that makes for goodness.

Long-standing congregants will know from previous sermons that the most important influence on my moral development was cowboy films. In Sam Peckinpah's beautifully elegiac Western Ride the High Country, two ageing, cast-aside lawmen, played by Randolph Scott and Joel McCrea, transport gold from a mining camp to the bank. The Randolph Scott character tries to persuade his friend to steal the gold, citing how badly they have been used all their careers, putting their lives on the line for a few lousy dollars' pay. But Joel McCrea rejects him with the marvellous remark: 'I want to enter my home justified'.

When that day comes, we would all wish to enter our home justified. The long hours of Yom Kippur give us the annual opportunity to examine and justify our lives by eternal standards. I for one am content to link myself with those who have gone before and those who will 
come after in the chain of Jewish tradition by describing those eternal standards as given by God and required of us by God. May we all use the coming hours wisely and well, at one with a God in whom we can honestly believe.

\section{Rabbi Harry Martin Jacobi, MBE, 19 October 1925-24 April 2019}

Rabbi Jacobi was born Heinz Hirschberg in Berlin. He was one of three boys who attended the same Jewish school in Berlin, including John Rayner and Albert Friedlander, all of whom went on to become rabbis in the UK. His was the last Bar Mitzvah to take place at the Friedenstempel in Berlin before Kristallnacht, 1938. He escaped Germany, initially for the Netherlands in 1938 and then to Britain in 1940, arriving as a Kindertransport refugee on the last ship to leave the Netherlands. Most of his family members who remained in Germany died in the Shoah.

He spent the war years in Manchester, volunteered for the Jewish Brigade and served from 1945 to 1948 as a driver in Belgium, France, Germany and Holland. In 1949 he attended the World Union for Progressive Judaism (WUPJ) conference in London and was persuaded by Rabbi Dr Leo Baeck's presidential address to become a rabbi. Encouraged by the Hon Lily Montagu, he was supported in his rabbinic studies and made up for his interrupted education with a BA in Hebrew, German and Dutch. Ordained as a 'reverend' in 1961, he received rabbinic ordination in 1971. Through the WUPJ Youth Section pen friend programme, he met his wife Rose, then secretary of the Young Men and Women's Hebrew Association in Bombay. They married in April 1957.

He served Southgate and District Liberal Synagogue (1956-1975), Wembley and District Liberal Synagogue (1975-1982) and Zurich Liberal Synagogue (1982-1990). In semi-retirement he served other Liberal Synagogues in the UK and for ten years was Chair of the Liberal Judaism Rabbinic Board. ${ }^{2}$ He was awarded the MBE in 2006 for his contribution to the life of the Jewish community and to interfaith relations. He was one of the officiating rabbis at the annual AJEX (Association of Jewish Ex-Servicemen and Women) Remembrance Service at the Cenotaph. He campaigned on behalf of refugees and in 2016 visited the 'Jungle', the migrant camp in Calais. His wife Rose died in January 2014 and in December 2016 his son David, who suffered early onset dementia.

Rabbi Jacobi is survived by his daughter Rabbi Dr Margaret Jacobi and his son Rabbi Richard Jacobi and his five grandchildren. 
The following sermon, 'Mei-Evel leSimchah - from Mourning to Joy', was given by Rabbi Jacobi on Yom Kippur before Neilah, in German in Zurich and subsequently in English (Thanet 1993, Wimbledon 2002, Brussels 2003). It was selected for this memorial by his two rabbinic children who added the two footnotes. They introduce it:

We chose this sermon partly because it shows our father's life-long love of Beethoven, and especially his Ninth Symphony with its message of joy and harmony. It is, of course, topical now in relation to the European Union. The message of the sermon clearly meant a lot to him as he gave it in four congregations. It reflects his optimism and faith, his determination always to be positive and to celebrate the good in life with joy. Despite his difficult beginning, he often said how fortunate he was, coming to this country with only a pair of pyjamas, to have a family, home and friends, grandchildren and great grandchildren.

We have all become familiar with a tune, now known as the European Anthem. It comes from Beethoven's Ninth [Symphony]. Those of us familiar with this great, monumental work will know its unusual structure. The first two movements have a great force and dramatic intensity, are full of turmoil and are most emotional. But the third movement is slow, quiet and calm, and the mood is of contemplation and serenity. That was the mood of our Yizkor (memorial) service. And then in the last movement comes the plea sung by the baritone soloist: 'O Freunde, nicht diese Töne! Sondern lasst uns angenehmeren anstimmen, und freuderenvolleren - $\mathrm{O}$ friends, no more these sounds continue, let us raise a song more pleasant and joyful'. That is exactly what we must say to each other now.

We have reached the most poignant, moving and serene moment of this great, holy Day of Awe. Yizkor has turned our thoughts, our memories, to parents and grandparents, to generations that preceded us. We are saddened, but also becalmed, resigned, at peace with ourselves and with our dear ones. Yizkor has engendered feelings of renewed hope and love and peace in all of us. And now we turn to Neilah, the concluding service.

We cannot and should not leave this day, this service, in a mood of contrition, gloom and sadness. As Beethoven showed and taught us, we should embrace each other in joy, for we know that a loving father lives in the heavens above, who wants us to live and serve each other in joy.

Neilah is a marked contrast with all other services on the Holy Days. For at Neilah the mood changes radically. The liturgy is recited joyfully, set to jolly tunes. We start Neilah by singing El Nora Alilah to a jolly, cheerful tune.

A passage in the Talmud tells us: 'There were no festive, joyful occasions in Israel to equal the 15th of Av and Yom Kippur, the Day of 
Atonement; for on those days, the sons and daughters of Jerusalem went out and danced in the vineyards' (Taanit 26b). Similarly, after the High Priest had completed the ritual, washed and changed into white linen, he re-appeared, and a shout went up and there was great rejoicing. As Bing Crosby used to sing: 'It's a good day for curing your ills'. This is how the day was regarded, beginning with solemnity, ending joyfully. Sukkot, zeman simchateinu, the most joyful festival in our Jewish year, follows only five days after Yom Kippur; as if to say to us: 'Do not dwell on your shortcomings, failings and sins, and be gloomy and depressed too long, do not unduly prolong your penance, but turn Miyagon lesimcha, from sadness to joy, as soon as possible. We are a sturdy, tough, indestructible people precisely because we are an optimistic, happy, joyful people. Not less than six times in Deuteronomy we read the Divine command 'vesamachta - you shall rejoice'. 'You shall rejoice in all the good which the Eternal One your God has given you and your household; you, the Levite and the stranger in your midst' (Deut. 26:11).

Every doctor and psychiatrist will confirm that patients of a happy, optimistic disposition have a far greater chance of recovery and are able to withstand illness better than a gloomy, sad, pessimistic patient. How right was the Psalmist to exhort us: 'Ivdu et Adonai b'simchah - you shall serve the Lord in joy' (Psalm 100:2).

It is a sad, sobering fact of modern Jewish life that most Jews come together on the solemn Days of Awe, gloomy, contrite, penitent, but not on the most joyful festival of Sukkot. It is a fact that would have mystified and puzzled the Talmudic Rabbis, as it mystifies and puzzles modern Rabbis. Jewish tradition has no justification for it, no explanation to offer. A modern psychiatrist might be able to explain. The fact remains that a Kehillah, a congregation where all come on the Holy Days, the Days of Awe, and few come on Sukkot, is Jewishly unbalanced, unhealthy. The biblical commands are explicit and emphatic: 'Shelosh pe-amim bashanah yeira-eh kol zechur'cha el p'nei ha-adon Adonai - 'three times a year (on Pesach, Shavuot and Sukkot) you shall all appear before the Sovereign, the Eternal One' (Exodus 23:17). All ${ }^{3}$ are commanded to come to the Temple on the three festivals, not on Rosh Hashanah and Yom Kippur. And today many come on Rosh Hashanah and Yom Kippur, few come on the three festivals. If one year we reverted to the biblical way, all came on Sukkot and only few on Rosh Hashanah and Yom Kippur, we would be so much stronger, for Nehemiah realised, and we should too: 'Chedvat Adonai, hi ma-uz'chem - the joy of the Lord is your strength' (Neh. 8:10). ${ }^{4}$ Chedvat Adonai - the joy of the Lord has always been the hallmark, strength and the chief characteristic of our Judaism, the foundation, the spark, of our Jewish spirit.

Let not contrition and gloom, the recitation of Ashamnu, dominate our Jewish lives. Let us now quickly turn from sadness to joy, from Yizkor to Neilah, let Chedvat Adonai, the joy of the Lord, pervade and dominate 
our lives, give us increased steadfastness and strength, so that in the coming year the fervent prayer and desire of the Psalmist will be fulfilled: 'Adonai oz le-amo yitein, Adonai yevarech et amo bashalom - the Lord will give strength to His people, the Lord will bless His people with peace' (Psalm 29:11).

\section{Rabbi Dr (HC) Ernst Max Stein, 10 May 1929-21 March 2019}

Born in Mannheim, as a child Rabbi Stein experienced Kristallnacht and saw the results of the invasion of the family flat by Nazis. On 7 September 1940, alone with his mother, they fled from Germany to Moscow and, through a long and tortuous journey, made their way to Shanghai. They lived there in extreme poverty, which had serious long-term effects on his health. He celebrated there his Bar Mitzvah, and at age fourteen began to work as an apprentice in a metal workshop that, much later, gave him the basis of a professional career. After the war, they moved to Palestine where they were reunited with his father and brother. There, too, he met his wife Ruth. In 1958 they moved to America where he was employed in a metalworking company, until ill-health forced him to take early retirement. A visit to Germany convinced him of the need for rabbinic leadership for the surviving Jewish community and he was encouraged by Rabbi Peter Levinson ${ }^{5}$ to undertake rabbinic studies. At the time, few rabbis were prepared to take up such a post, and Jews were generally antagonistic to the idea that there should be a Jewish presence in Germany. To which Rabbi Stein responded: 'It is an academic point whether Jews should live in Germany. History has spoken. There are Jewish communities in Germany and as long as they are here, they should be served'.

Despite never having completed a formal education, he resolved to undertake the rabbinic programme and was accepted at Leo Baeck College in 1973. Following ordination in 1976, he began to work as a rabbi in the UK and in 1980 was called to Berlin on a five-year contract to become the rabbi of the Liberal Synagogue in Pestalozzi Strasse, though with far broader responsibilities in the community. With Kantor Estrongo Nachama, they regularly crossed over to East Berlin to provide High Holy Day services to the small Jewish community there and do pastoral work. The five-year contract extended to seventeen years until he retired in 1996. With a home in the UK, he continued to return regularly to Berlin to work on a part-time basis. In 2009, his eightieth birthday was publicly honoured by the Berlin Jewish community. In November of that year, the Humboldt University bestowed on him an Honorary Doctorate. ${ }^{6}$ 
In Mannheim, Rabbi Stein concluded his sermon to mark the 150th anniversary of the deliberately destroyed old synagogue (29 June 2005) with the words:

Commemorations always stir up things; old wounds hurt again. Nevertheless, we are a community of hope and of bearers of hope; and we, together with all people of good will, work towards a better future. The splendid old main synagogue, its commemoration, should offer light on the path to this future, luminous signs of the power and will of the Jewish community of this town. ${ }^{7}$

Rabbi Stein is survived by his daughter Charlotte and his son Robert and his three grandchildren.

In an unpublished autobiographical memoir, provided by his son Robert, Rabbi Stein recounted his life from the difficult years as a child during the rise of the Nazi Party, the refugee experience in Shanghai, his activities in Palestine/Israel during the War of Independence and the Suez Crisis, his life in America and his decision to enter the rabbinate. He describes the challenges of working with the Jewish community of Berlin:

But let me remember chronologically these long seventeen years of my active Berlin time.

In retrospect it might all sound so easy and pleasant, but to be rabbi to a large and very diverse congregation is no laughing matter at anytime, anywhere, but the Jewish post-war German communities and especially the Berlin community were and still are very, very difficult. Let us first examine the makeup of the membership that will give us some clue to the problem. Who were my congregants? There were, first of all, a number of Jews who had, in a number of ways, survived the Shoah in Berlin. They may have been in hiding, helped by decent Germans, lived in a mixed marriage, or just slipped through the meshes of the net. They were there directly after the war and they were the nucleus of the new congregation. Then there were the many that came out of the concentration camps or were liberated in the Berlin area. Many of them came to Berlin, which was, though severely destroyed, a large city, under allied occupation, which offered some shelter and help. Not all stayed in Berlin, many left, others came. All these people together with some, not many, who came to Berlin during the next decades, for their own reasons, and not forgetting the children born there, made up the membership of the Berlin Jewish Community, and stabilized its numbers at about six thousand. So, we see that it was a mixed membership, with varied interests and social backgrounds. There were members who, although living in Berlin for the last thirty-five years, spoke barely any German, they had 
chosen not to; on the other hand there were some who had apparently forgotten what had happened and lived almost to Prussian standards. There were quite a number of mixed marriages; in some, but by all means not all cases, the spouse converted to Judaism. In the 1970s, Jews from the Soviet Union began to arrive in Berlin and a process started that would transform the community. I stepped into this very mixed congregation, to begin my service for the next seventeen years....

The Berlin community had a disproportionally large number of elderly people and therefore there were a great number of funerals to attend to; all told, I officiated at more than twelve hundred funerals, many together with chief cantor Nachama. During the years we became a very efficient team. Some of the funerals are worth mentioning. There was the case of a known pimp who had passed away; there were a number of ladies of the horizontal profession in attendance. What do you say in the eulogy? That he was a good provider? Or there was the funeral of a Russian man, whose son was brought to the cemetery, handcuffed to a policeman. As the widow was also to be arrested, for whatever offence it may have been, the police tried to arrest her while coming out of the cemetery. A riot broke out. Police reinforcements had to come, a police car was overturned, the woman was arrested. At last I managed to bring some order into the chaos. It is not everywhere that one gets an experience like that....

One very important aspect of my work was the contact with representatives of the churches and other organisations.... For years I lectured on a regular basis at 'Volkshochschulen' Institutes for adult education, all over Berlin; some of these lectures were held under the auspices of the AKR, the Berlin association of churches and religious organisations. It was sometimes a very strange feeling to speak to an assembly of elderly people on some particular subject of Judaism, knowing full well that some of them may well have been members of the BDM or the HJ, the Nazi youth organisations; but by and large I never had any incident.

Almost from the very beginning of my service in Berlin, I had my radio time, on a regular basis, with both the major stations in Berlin, RIAS and SFB. Our time was mostly for Friday night and festival occasions, but I also for more than six years did a weekly, ten-minute monologue on a Jewish subject for the ORB and therefore have a collection of over three hundred manuscripts, for that purpose alone.

From 1982 I also visited the East Berlin Congregation on a more or less regular basis and helped them, especially in lifecycle events, whenever necessary. For a number of years, I led their Seder, the second night of Passover. During all those years I never missed leading the first Seder night in my congregation, an event with up to four hundred participants.... As the years went by, I became a fixture of and accepted in East Berlin. I received a permanent visa to cross the border, did not 
have to exchange any moneys, was permitted to stay overnight and never had to show a manuscript before speaking. I also was invited to participate in East German church conventions, where I was allowed to speak and participate freely. In 1988 I was offered the post of 'State Rabbi' to East Germany, which I politely declined, although I was promised that I could remain living in West Berlin and would be picked up by my 'official limousine' whenever I wanted. It must be understood that part of all this was a desire by East Germany to have Mr Honnecker invited to the USA, to show the normality of conditions of the East German Jewish communities. These Jewish congregations were few in number and some only had a handful of members. East Berlin being the largest had to my estimation fewer than two hundred members; in addition, the Jewish status of many of those members was more than questionable. Nevertheless, these congregations had all the institutions a congregation needs, and they were, at the time, thankful for the help I could give them.

\section{Rabbi Charles David Wallach, 5 February 1950-23 August 2019}

Rabbi Wallach was born in Johannesburg, South Africa, pursued Biblical Studies and Hebrew at Witwatersrand University (1968-1971), and, from 1971, studied at Leo Baeck College, where he was ordained in 1975. He served as rabbi of the United Progressive Jewish Congregation of Johannesburg (1975-1977), Brighton \& Hove Progressive Synagogue (1977-1988) and Temple David Congregation of Perth, Australia (1988-1995). Deeply committed to Israel, the family made Aliyah and while studying to become a tourist guide, Rabbi Wallach led conversion classes at two Jerusalem synagogues and served as a part-time rabbi of a small Reform congregation in Nahariya. In 2000 he was urgently called to become rabbi at Bet Menorah Congregation, Pretoria, South Africa (2000-2002) and subsequently served in Temple Emanuel Congregation, Johannesburg (2003-2007), working also as Executive Director of the South African Progressive Movement. He returned to the UK and served the Brighton \& Hove Reform Synagogue (2008-2012). At other times he acted as a self-employed rabbi, helping out in congregations without rabbinic services. During his career he was actively engaged in interfaith work, hosted his own radio programme in South Africa, and in the UK was Chaplain to the NHS in Sussex. ${ }^{8}$

Rabbi Wallach is survived by his wife Marilyn, two daughters, nine grandchildren and a great-granddaughter. 
Following the death of Nelson Mandela, Rabbi Wallach circulated the following letter to rabbinic colleagues on Friday, 6 December 2013:

Dear colleagues,

Allow me to add a word on the passing of Nelson Mandela, for, perhaps alone among colleagues, I had a unique perspective on him.

I was born in Johannesburg just after the 1948 elections which brought the National Party to power, heralding what eventually became apartheid. Prior to that date South Africa was already an unequal society and based on race to a large degree, but those 'non-whites' who either had sufficient income or capital or education were able to participate in the wider society.

Mandela, as is known, studied at the University of Witwatersrand then Johannesburg's only university - and became a lawyer. He was in fact articled to a Jewish lawyer before embarking on a partnership with the express aim of improving the lot of the black people in South Africa.

I well remember the late 1950s and early 1960s when he and his fellow freedom fighters were first put on trial and then imprisoned. The government did its best to demonise these people - somewhat mystifying to me who had had swimming lessons at the home of one of these families and regularly saw one of the white 'co-conspirators' walk from his home near to ours to our local police station to sign in during his period of house arrest (that walk being his only permitted escape from home).

Mandela was among the greatest of these 'demons'. I had followed the trial held in Pretoria's 'old synagogue'. The reason it was there was that the court building nearby was too small. Pretoria's orthodox synagogue had then recently been sold as a new one was being built in the area where the community was then principally living. I remember once being in that building for the centenary of Pretoria's Jewish community: it was a huge barn of a place.

I too studied at Wits as we called it. By then (in 1959 in fact) the universities had been closed to blacks. Wits along with those of Cape Town, Natal and Rhodes in the Eastern Cape gamely tried to fight against apartheid. Annually a 'Freedom Lecture' was held at which famous overseas speakers spoke to champion the cause of freedom: Robert Kennedy, former Eton head Birley, Labour MP Joan Lester and Denis Healy were among those I remember. And we would protest the excesses of the government in our time for they were many.

People such as Helen Suzman - my own Member of Parliament as it happened (later she became a congregant of mine!), Donald Woods who championed the cause of Steve Biko and many others were to inspire us as Mandela and the others were recalled and efforts made to release them.

Some of the eventual leaders of the new South Africa had fortunately been abroad or had slipped out of the country. So, when I eventually 
came to Brighton in 1977 I discovered that Thabo Mbeki - Mandela's successor in time - was a student at Sussex and that the main hall on campus was called Mandela Hall.

I served as Rabbi in South Africa twice. First from 1975 to 1977. Apartheid was still heavily in force. As a child I had seen the effects of Sharpeville and the creation of the republic outside the Commonwealth. As a newly ordained rabbi I witnessed the Soweto uprising of 1976. In the immediate aftermath of each of these events we saw both a tightening of apartheid and an exodus of many of our community.

I too left in 1977 and honestly never thought I would return except for visits. In 1999, however, I was asked to spend three months helping our Pretoria community which had recently parted company with its Rabbi. Mandela had just stepped down from his single 5 year term as President. Yes, I was aware of change but in those few months it seemed but cosmetic. My decision to return on a proper basis a year later changed that for me.

In the seven years in which I served there I experienced both the good and the less so in South Africa. Yes, we had to be constantly vigilant the 'threat' coming not from those who wanted to overthrow the government but from those who had been denied education, housing, work opportunities, or who were just out to get what they could. We were burgled twice and once endured an attempted 'car-jacking'. My wife had her car stolen, and kindness in giving accommodation to someone was 'rewarded' by her purloining some of her clothes.

But the motivation to build a positive society remained strong within us: Our movement in South Africa had, as far back as 1945, built a school for the black population. That school - named for the founding Rabbi of our movement there - M.C. Weiler - now has 2000 students and retains its strong links with our movement. In every area where the Jewish community is, we, along with others, play a part alongside other South Africans of every hue.

And, from a rabbinic perspective further benefits grew. Mandela created something called the National Religious Leaders Forum - an interfaith body to oversee moral and religious development in that land. It would meet regularly as a body and at least once a year in the Cabinet Room in Pretoria together with the President. I served on that body for four years when Mbeki was President. Through it, doors were opened, old prejudices diminished, and new perspectives put in place. All this seems 'old hat' here - but there the divisions had been deep. It took effort to break attitudes.

One small but significant result was when I decided to have the children of my Johannesburg congregation run a project. Through my connections I became aware of a charity which bore Mandela's name and whose headquarters were nearby. Its purpose was to provide a place for families to stay: Not just any families but families whose children 
needed long or mid-term hospital stays in Johannesburg. The families were mostly rural blacks who had little means of being near their dear ones. Again, here and elsewhere such things are commonplace: In South Africa they had previously been unheard of. Our little bit of money may have provided toys and toiletries for the families: But more importantly it made us aware of such places - and their being there was part of the Mandela legacy.

I never met Mandela but I was in his presence just once. As national director of our movement I was invited to the installation of Mbeki in 2004 as he embarked on his second term in office. The ceremony took place in Pretoria with crowds of dignitaries and also many invitees who were of middle ranking status - officials, local councillors and the like.

As each of the top people arrived cheers and singing rang out: The greatest though were for Mandela - by then aged nearly 86 . He walked in on the arm of his wife Graca Machel - in his trademark shirt of course no dark suit for him! He smiled his broad smile and waved to the gathering before taking up his appointed seat.

He may have been officially a bystander to proceedings as Jewish Chief Justice Arthur Chaskelson administered the oath of office to Mbeki - but clearly it was Mandela who was effectively presiding - his mere presence exuding the hope that Nkosi Sikeleli Afrika - that God will truly bless (South) Africa.

Charles

Rabbi Professor Jonathan Magonet is Emeritus Professor of Bible at Leo Baeck College, author of Talking to the Other: Jewish Interfaith Dialogue with Christians and Muslims and editor of European Judaism.

\section{Notes}

1. Rabbi Dr Jeremy Collick, 'Only the Lonely' Masorti Judaism, 11 July 2016, https://masorti.org.uk/newsblog/newsblog/news-single/article/only-the-lon ely.html\#.XiIfPsj7TIU (last accessed 11 February 2020).

2. Biographical information is from Abigail Jacobi, 'Rabbi Harry Jacobi Biography', in Responding to the Call: A Life of Liberal Jewish Commitment: A Festschrift in Honour of Rabbi Harry Jacobi MBE, ed. Danny Rich (London: Liberal Judaism, 2015), 11-16.

3. Though the text states 'all your males', its scope is widened to be inclusive.

4. The full verse adds to the rhetorical point: Nehemiah said, 'Go and enjoy choice food and sweet drinks, and send some to those who have nothing prepared. This day is holy to our Lord. Do not grieve, for the joy of the Lord is your strength' (Neh. 8:10). 
5. 'In Memoriam - Nathan Peter Levinson z'l', European Judaism 50, no. 1 (Spring 2017), 159-162.

6. The papers delivered at that event are to be found in European Judaism 44, no. 2 (Autumn 2011), 4-17.

7. Quoted in a memorial tribute to Rabbi Stein, 'Mahner und Gelehrter' by Rabbiner Andreas Nachama, in the Jüdische Allgemeine (26 August 2019) (translated by JM).

8. Some of the information is obtained from the Hesped delivered by Rabbi Elli Tikvah Sarah at the funeral on 29 August 2019 at Old Shoreham Road Cemetery, Hove. 
The Board of Editors welcomes articles, letters and comments for publication.

The Managing Editor, European Judaism

Leo Baeck College, The Sternberg Centre

80 East End Road

London, N3 2SY UK

Any material submitted for publication should be supplied on disk, accompanied by one double-spaced hard copy, and a brief biographical note on the author. Authors whose contributions are selected for publication will be required to submit a short abstract and list of key words prior to publication.

Please refer to the Info for Authors page on the website for submission and style guidelines.

Please also refer to the Journal Contributors' page on the website for general information and guidelines regarding topic such as article usage and permissions for Berghahn journal article authors.

Books for Review should be sent to:

The Managing Editor

European Judaism

LBC-CJE

The Sternberg Centre

80 East End Road

London, N3 2SY UK

E-mail: european.judaism@lbc.ac.uk

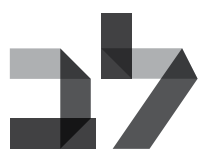

European Judaism is not an official organ, nor do the publishers and editors necessarily identify themselves with the views expressed in its pages. 